International Research Journal of Management, IT \& Social Sciences
Available online at https://sloap.org/journals/index.php/irjmis/
Vol. 8 No. 2, March 2021, pages: 184-195
ISSN: 2395-7492
https://doi.org/10.21744/irjmis.v8n2.1425

\title{
Work Climate and Employee Performances: A Literature Observation
}

Julia Permatasari ${ }^{\text {a }}$ Intan Ratnawati ${ }^{\text {b }}$

Article history:

Submitted: 27 January 2021

Revised: 18 February 2021

Accepted: 09 March 2021

\section{Keywords: \\ conceptual analysis; employee performance; literature review; performance improvement; work climate;}$$
\text { Work climate; }
$$

-

\section{Corresponding author:}

\section{Permatasari, J.}

Master's Degree Program in Management, Faculty of Economics and Business, Diponegoro University, Semarang, 50241, Indonesia

Email address: juliapermatasari95@gmail.com

\begin{abstract}
This article mainly discusses the relationship between work climate and employee performance. Research on the relationship between work climate and employee performance still shows mixed results. The purpose of this study was to determine the relationship between work climate and employee performance by comparing the results of primary research on these two variables. The method used is a conceptual analysis of various previous studies in the last ten years. The results show that there is a significant and positive relationship between work climate and employee performance, especially in the Indonesian context where social relations take priority in society. This implies that managers must be able to create a favorable work climate to encourage employee performance improvement, although this is not the only thing that must be considered.
\end{abstract}

International research journal of management, IT and social sciences () 2021. This is an open access article under the CC BY-NC-ND license (https://creativecommons.org/licenses/by-nc-nd/4.0/). 


\section{Introduction}

Employee performance is one of the benchmarks of success for an organization. Fundamentally, organizations are aiming to achieve their goals. Hence, employee performance becomes the most important factor that needs to be observed. Employee performance is an important part of the company to improve the effectiveness of human resources (Snell \& Bateman, 2018; Fay \& Lührmann, 2004; Hellriegel \& Slocum, 2004). This is because employee performance will relate to some or all of the activity actions of an organization at a period with a reference to some standards such as past costs projected based on efficiency, accountability or management accountability and the like in achieving its objective (Rivai, 2013). Employee performance is defined as the achievement of the work of a person or group of individuals following the authority and responsibility after exerting the necessary efforts on the related work (Hellriegel et al., 1999; Karakas, 2010).

Therefore, due to the importance of employee performance in measuring an organization's productivity, some research regarding factors that are affecting employee performance is conducted. Amongst the factors affecting employee performance, work climate or working environment becomes one of the factors evaluated ( He, An, \& Li, 2015). Work climate and its components are considered significant in predicting employee performance for an organization (Abubakr \& Bader, 2013; Duchon \& Plowman, 2005; Kapp, 2012). Organizational work climate then must be one of the things to be observed by managers because this factor directly affects and forms the working environment (A. D. Diamantidis \& Chatzoglou, 2019). A positive and constructive work climate is the important thing to be able to motivate employees. A positive work climate will affect the high motivation of work responsibilities, commitments, worker engagement, job satisfaction, and work discipline and as a result increase work productivity. In short, a positive working climate will be more successful over time as it increases emotions and positive well-being (Emma \& Kim, 2015). Managers must be able to evaluate work climate and uses their experiences to be able to change and improve management practices that will motivate employees to perform better and keep on improving.

But then, research regarding the relationship between work climate and employee performance up until recently still shows various results. Though most of the research shows that there is indeed a connection between work climate and employee performance (Li, Yee Poh \& Mahadevan, 2018). But some researchs show otherwise. Delft (2010) found that the working climate consists of many dimensions. The results of previous studies show that from several dimensions of the working climate that has a significant influence on employee performance only Innovation. Meanwhile, responsibility, Reward, Clarity, standards have no significant effect. Kusmaningtyas \& Priyana (2013) also found similar results that employee performance is not affected by work climate. Those studies show that each employee's performance in their daily working activity in accordance to their responsibility and authority is not affected by internal environment quality, but it is affected by personal behavior instead, as the characteristics are shown.

Based on mentioned observation, the purpose of this study is to conduct a conceptual observation for existing research literature by comparing results obtained in each research and then obtaining an entire understanding of the relationship between work climate in an organization and employee performance. This research will contribute to developing knowledge about the relationship between work climate in an organization and employee performance and providing a conceptual framework that can be used in further studies development.

\section{Literature Review and Research Model Development}

\section{Employee Performance}

Fundamentally, performance represents the amount of work a person can finish in a certain given time. Performance can be considered an accomplishment of a program or policy in the realization of an organization's objectives, goals, vision, and mission policies that impact the objectives, vision, and mission of the organization through the strategic planning of an organization (Shilpa, 2015; Kawiana et al., 2018; Neal et al., 2000). While employee performance is" Employee performance can be defined as "the result of a person or group's works in accordance to their responsibility or authority of each employee in certain period" (Rivai, 2013). There are performance measurement that is related to performance criteria based on specific behaviors, such as (Faustino Cardoso, 1995):

1) Quantity of work, is the work result obtained in a certain given period.

2) Quality of work, is the work quality obtained based on congeniality and readiness requirements.

3) Job knowledge, the extent of knowledge regarding the job and required ability.

4) Creativeness, is ideas originality and actions to solve emerging problems.

Permatasari, J., \& Ratnawati, I. (2021). Work climate and employee performances: a literature observation. International Research Journal of Management, IT and Social Sciences, 8(2), 184-195.

https://doi.org/10.21744/irjmis.v8n2.1425 
5) Comparative, is willingness to work together with others (between organization members).

6) Dependability, is awareness and reliability in terms of presence and work accomplishments.

7) Initiative, is passion to finish new tasks and increasing their responsibility.

8) Personal qualities is involving personalities, leadership, hospitality, and personal integration.

According Anastasios D. Diamantidis \& Chatzoglou (2019), terdapat dua hal utama yang dapat mempengaruhi kinerja karyawan, yaitu faktor individu dan faktor lingkungan organisasi. Individual factors mainly relate to intrinsic motivation, skill flexibility, skill level, proactiveness, adaptability, commitment. While the organization's environmental factors are related to the working climate, autonomy of work, communication.

\section{Work Climate}

Employee perceptions regarding their environment work in an organization are called climate work according to Robbins and Coulter (Robbins \& Coulter, 2016; Pant \& Yadav, 2016; Permarupan et al., 2013). A good work climate is considered able to encourage an organization's survivability. This will encourage the employee to be able to adapt towards processes within the organization, and improving individual abilities, team, and every involved party of an organization.

Work climate can also be represented as a condition where employees feel safe, composed, and comfortable in doing their job and can increase motivation and impact the work environment (Hicklenton et al., 2019). Working environment then becomes one of the important factors on work climate. Working environment is viewed to be able to either directly or indirectly influence people inside an organization. Work climate greatly affects the behavior of individuals within the organization (Subramani et al., 2016). It concerns the environment that exists or that an individual faces within an organization and affects a person in performing a task or job (Keith \& Davis, 2001).

Working environment and work climate in an organization include two main components, such as physical and psycho-social aspects. Physical environment in work climate are given more concerns and considered to be more important in literature development regarding work climate. Physical environment then assumed to be main consideration of employee performance. Research about influence of physical environment, such as lighting, temperature, noise level, and atmosphere situation towards employee performance, doesn't find that there is a significant relationship between physical environment element and employee performances (Sleight \& Tiffin. \& Vickroy, Shaw, 1997). Later, this encourages research regarding relationship between social and psychological climate in workspace and their influences towards employee performance and behaviors. Psycho-social climate is consiered important in the development of "quality of work life (QWL)" (Abubakr \& Bader, 2013; Shanker et al., 2017). This encourages observations regarding organization's climate must involve these both aspects to get more comprehensive results.

Research conducted by Jyoti (2013) proves that with a pleasant Work Climate will improve work-related performance. Thus the study conducted by Bamel et al. (2013) show that the existence of a conducive Work Climate can improve the effectiveness of management. Agarwal (2015) proves that Work Climate is a mediation in improving performance. Some factors encourage the formation of good climate work, such as followings (Lamberti et al., 2020):

1) Organization's vision - management's vision (vertical vs horizontal), culture/ethic orientation, management capacity to make good decision, and willingness of management to inform employees about the condition of the organization and the direction it is moving towards.

2) Superiors - relationship between employees and their direct superiors and professional ability, also leadership they experience from managers.

3) Colleagues- social climate between work partners, social sense of belonging, and cooperations between colleagues.

4) Physical environment - physical working environment, work safety, salary and allowance package, and all work aspects from sociocultural context of isolations.

5) Company's image - trust and reliability experienced by company; including numerous activities in accordance to formal communication through name, logo, nameplate, company advertisements, and public relations.

\section{Work climate and Employee Performance}

Numerous research has been conducted to study the relationship between work climate and employee performance. Some opinions consider work climate is more important or that it has more influence compared to ability or 
organization's technique in creating effective organization (Hadian, 2018). Work climate is related to environment where employees are doing their works and it will influence their behavior within organization, oftenly represented as organizational culture, hence involving in employee performance in accomplishing their tasks. Work climate will influence employee performance as shown on how employee can accomplish their task well. Subramani et al. (2016) stated that there exists a correlation between organization climate with employee performance. In this context, organization climate is a numerous measurable behavior from organization envionment based on collective perceptions of employees within that organization.

Work climate is considered important factor within organization to be able to achieve its goals. Conducive climate within organization will encourage well accomplished tasks (Hafee et al., 2019). Especially when work climate within organization can improve working passion, which then will accelerate task accomplishment that becomes employee responsibility. Therefore, good work climate will improve employee performance, represented in the increase of productivity. High productivity within organization proves that environment where individuals work is in conducive state because high work satisfaction of an organization (Putra, 2018).

\section{Materials and Methods}

This study is a qualitative study, in which literature study is used. Data used in this study is secondary data. Reviews were conducted towards numerous earlier research. Hence, this study is conducted conceptually in accordance with earlier research regarding the relationship between work climate within organization and employee performances. Literature used as references in this study is limited to that of ten years intervals.

\section{Results and Discussions}

Literature review towards various research regarding the relationship between organizational climate and employee performance has been conducted. Reviews were conducted on the results of research that lasts in the last 10 years, either national or international publications. But, literature that was written in Indonesian studying about the relationship between work climate and employee performance are most likely to be found compared to that of international publications regarding the same problems. In general, results show that reviews towards the relationship between organizational climate and employee performance were using the quantitative method. Table 1 shows various findings regarding the relationship between organization climate and employee performance.

Table 1

Relationship between work climate and employee performance

\begin{tabular}{|c|c|c|c|}
\hline Researcher/year & Research Aims & Method & Results of the study \\
\hline $\begin{array}{l}\text { Raja. S, Madhavi, \& } \\
\text { Sankar (2019) }\end{array}$ & $\begin{array}{l}\text { This study was conducted } \\
\text { to determine the Impact of } \\
\text { The Organization's } \\
\text { Climate on Employee } \\
\text { Performance in } \\
\text { Manufacturing industry }\end{array}$ & Quantitative & $\begin{array}{l}\text { From this study it was found that } \\
\text { there is a significant relationship } \\
\text { between the organization's climate } \\
\text { with respect to employee } \\
\text { performance. There is a positive } \\
\text { relationship between variables. The } \\
\text { analysis found that orientation, } \\
\text { interpersonal relationships, } \\
\text { managing problems, managing } \\
\text { conflicts, reward management, risk- } \\
\text { taking, }\end{array}$ \\
\hline Delft (2010) & $\begin{array}{l}\text { Organizational Change } \\
\text { Readiness for } \\
\text { Implementing ISO15288. } \\
\text { Testing the Relationships } \\
\text { between Change Valence } \\
\text { and Change Commitment }\end{array}$ & Quantitative & $\begin{array}{l}\text { Iklim organization consists of many } \\
\text { dimensions. The results of previous } \\
\text { research showed that from several } \\
\text { dimensions of the organization's } \\
\text { climate that has a significant } \\
\text { influence on employee performance }\end{array}$ \\
\hline
\end{tabular}

Permatasari, J., \& Ratnawati, I. (2021). Work climate and employee performances: a literature observation. International Research Journal of Management, IT and Social Sciences, 8(2), 184-195.

https://doi.org/10.21744/irjmis.v8n2.1425 


\begin{tabular}{|c|c|c|c|}
\hline & & & $\begin{array}{l}\text { only Innovation. Meanwhile, } \\
\text { responsibilitiy, Reward, Clarity, } \\
\text { standards have no significant effect. }\end{array}$ \\
\hline Berberoglu (2018) & $\begin{array}{l}\text { The purpose of this study } \\
\text { was to analyze the } \\
\text { organization's climate } \\
\text { impact on the } \\
\text { organization's commitment } \\
\text { and perceived } \\
\text { organizational } \\
\text { performance: empirical } \\
\text { evidence from public } \\
\text { hospitals }\end{array}$ & Quantitative & $\begin{array}{l}\text { The results revealed that the } \\
\text { organization's climate is strongly } \\
\text { correlated with the organization's } \\
\text { commitment and perceived } \\
\text { organizational performance. Simple } \\
\text { linear regression results show that } \\
\text { the organizational climate is } \\
\text { significant in predicting } \\
\text { organizational commitment and } \\
\text { perception of organizational } \\
\text { performance. }\end{array}$ \\
\hline $\begin{array}{l}\text { Abubakr \& Bader } \\
(2013)\end{array}$ & $\begin{array}{l}\text { The purpose of this } \\
\text { research is to find out the } \\
\text { perceived working climate } \\
\text { and performance of } \\
\text { employees in public safety } \\
\text { organizations in the UAE }\end{array}$ & Quantitative & $\begin{array}{l}\text { The results showed that the climate } \\
\text { of the organization and its } \\
\text { components significantly predicted } \\
\text { its performance and factors. }\end{array}$ \\
\hline Thanh, (2018) & $\begin{array}{l}\text { The purpose of this study } \\
\text { was to analyze "How } \\
\text { spirituality, climate and } \\
\text { compensation affect work } \\
\text { performance" }\end{array}$ & Quantitative & $\begin{array}{l}\text { The findings suggest that there is a } \\
\text { strong, positive and significant } \\
\text { relationship between workplace } \\
\text { spirituality (involving work, a sense } \\
\text { of togetherness), workplace climate, } \\
\text { compensation and perceived work } \\
\text { performance. }\end{array}$ \\
\hline Amro et al. (2018) & $\begin{array}{l}\text { The purpose of this study } \\
\text { is to analyze knowledge } \\
\text { management, workplace } \\
\text { climate, creativity and } \\
\text { performance: Authentic } \\
\text { leadership roles }\end{array}$ & Quantitative & $\begin{array}{l}\text { Empirical results show that } \\
\text { authentic leadership positively } \\
\text { affects the workplace climate, } \\
\text { creativity and work performance; } \\
\text { workplace climate positively affects } \\
\text { creativity and work performance; } \\
\text { the workplace climate mediates the } \\
\text { relationship between authentic } \\
\text { leadership and creativity, and work } \\
\text { performance; and knowledge- } \\
\text { sharing behavior moderates the } \\
\text { relationship between authentic } \\
\text { leadership and workplace climate. }\end{array}$ \\
\hline Mutonyi et al. (2020) & $\begin{array}{l}\text { The purpose of this study } \\
\text { is to analyze the influence } \\
\text { of climate organization and } \\
\text { creative performance in the } \\
\text { public sector }\end{array}$ & Quantitative & $\begin{array}{l}\text { The findings show that the } \\
\text { organization's climate has an } \\
\text { important role in the creative } \\
\text { performance of employees. The } \\
\text { organization's climate showed a } \\
\text { positive and significant relationship } \\
\text { with the two creative performance } \\
\text { variables included in the study. In } \\
\text { addition, the study revealed that } \\
\text { individual creativity mediates the } \\
\text { relationship between the }\end{array}$ \\
\hline
\end{tabular}




\begin{tabular}{|c|c|c|c|}
\hline & & & $\begin{array}{l}\text { organization's climate and the } \\
\text { individual's innovative behavior. }\end{array}$ \\
\hline $\begin{array}{l}\text { Fenwick, C., \& Harald } \\
\text { (2011) }\end{array}$ & $\begin{array}{l}\text { The purpose of this study } \\
\text { is analyze organizational } \\
\text { climate and performance in } \\
\text { retail pharmacies }\end{array}$ & Quantitative & $\begin{array}{l}\text { A supportive climate tends to be } \\
\text { associated with higher } \\
\text { organizational performance (i.e. } \\
\text { financial performance, staff } \\
\text { satisfaction, customer satisfaction) } \\
\text { in small retail pharmacies, and can } \\
\text { reduce staff turnover. }\end{array}$ \\
\hline Nugroho et al. (2019) & $\begin{array}{l}\text { The purpose of this study } \\
\text { is to analyze the influence } \\
\text { of motivation and work } \\
\text { climate on the performance } \\
\text { of employees at Duta } \\
\text { Bangsa Surakarta } \\
\text { University. }\end{array}$ & Quantitative & $\begin{array}{l}\text { The working climate has no effect } \\
\text { on employee performance, but } \\
\text { together they affect the performance } \\
\text { of employees at Duta Bangsa } \\
\text { Surakarta University. }\end{array}$ \\
\hline $\begin{array}{l}\text { Prastiyono et al. } \\
(2020)\end{array}$ & $\begin{array}{l}\text { This study was conducted } \\
\text { to study the influence that } \\
\text { can be caused by } \\
\text { leadership style, } \\
\text { organizational culture and } \\
\text { work climate on job } \\
\text { satisfaction that will have a } \\
\text { chain impact on the quality } \\
\text { of employee performance. }\end{array}$ & Quantitative & $\begin{array}{l}\text { It was found that the work climate } \\
\text { negatively affects employee } \\
\text { performance, this is because the } \\
\text { work climate is seen as a dynamic } \\
\text { system concept. This means that the } \\
\text { climate in an organization is not } \\
\text { fixed, but can change to a better } \\
\text { atmosphere or vice versa. }\end{array}$ \\
\hline $\begin{array}{l}\text { Kusmaningtyas \& } \\
\text { Priyana (2013) }\end{array}$ & $\begin{array}{l}\text { This study aims to } \\
\text { determine the effect of } \\
\text { compensation and the } \\
\text { organization's climate on } \\
\text { work motivation and its } \\
\text { impact on the performance } \\
\text { of employees of PT Bank } \\
\text { XXX Tanjung Perak } \\
\text { Branch. }\end{array}$ & Quantitative & $\begin{array}{l}\text { The results of the analysis in this } \\
\text { study showed that the organization's } \\
\text { climate variables did not } \\
\text { significantly affect employee } \\
\text { performance. The organization's } \\
\text { climate must first generate work } \\
\text { motivation in order to improve } \\
\text { employee performance. }\end{array}$ \\
\hline $\begin{array}{l}\text { Abubakr \& Bader } \\
(2013)\end{array}$ & $\begin{array}{l}\text { The purpose of this paper } \\
\text { is to test the potential } \\
\text { relationship between } \\
\text { perceptions of the work } \\
\text { climate and work } \\
\text { performance within } \\
\text { security organizations }\end{array}$ & Quantitative & $\begin{array}{l}\text { The results showed that the climate } \\
\text { of the organization and its } \\
\text { components significantly predicted } \\
\text { its performance and factors. }\end{array}$ \\
\hline $\begin{array}{l}\text { Abdillah, Anita, \& } \\
\text { Anugerah ( 2016) }\end{array}$ & $\begin{array}{l}\text { This study aims to test the } \\
\text { organization's climate } \\
\text { impact on work stress and } \\
\text { employee performance. }\end{array}$ & Quantitative & $\begin{array}{l}\text { The results showed that the } \\
\text { organization's climate affects work } \\
\text { stress and employee performance. In } \\
\text { addition, these results also show that } \\
\text { the organization's climate influence } \\
\text { on employee performance is an } \\
\text { indirect influence through work } \\
\text { stress. }\end{array}$ \\
\hline $\begin{array}{l}\text { Khademfar et al. } \\
\text { (2013) }\end{array}$ & $\begin{array}{l}\text { This study aims to find out } \\
\text { the relationship between } \\
\text { Ethical Work Climate } \\
\text { (EWC) and Corporate } \\
\text { Performance. }\end{array}$ & Quantitative & $\begin{array}{l}\text { Based on the results of the study } \\
\text { found a high correlation and a } \\
\text { significant relationship between } \\
\text { EWC and Organizational } \\
\text { Performance (OP) in Malaysian }\end{array}$ \\
\hline
\end{tabular}


Alberto, Amar, \& Patrisia (2019)

Siregar \& Evanita (2020)

Permarupan et al. (2013)

Abdul-Nasser ElKassar et al. (2011)

Crespell \& Hansen (2008)
This study aims to analyze the influence of Leadership, Organizational Culture and Work Climate on Employee Performance

Research objectives to analyze the influence of Leadership, Organizational Culture and Work Climate on Employee Performance

The purpose of the research is to propose to review the organizational climate and the spirit of employee work and the commitment of the organization to academics of public and private universities in Malaysia.

The study investigated the effects of seven dimensions of the organization's climate (Structure, Responsibility, Risk, Appreciation, Warmth and Support, Conflict, and Expecting Approval) on three types of organizational commitments (Affective, Continuous and Normative). The purpose of this paper is to examine whether there is a relationship between every aspect of the organization's climate and any type of employee commitment. It seeks to integrate into unifying models the concept of a working, innovative, and assertive performance climate using companies. This suggests that the manager's perception of ethical behavior and ethical climate is positive.

Quantitative The results showed thati klim work has a significant and positive effect on employee performance.

The working climate in this case relates to the atmosphere and circumstances that describe the conditions of workers or concerns between eachother.

Quantitative The results showed that the work climate has a significant impact on employee performance which means that the work environment is one of the important variables and can improve employee performance.

Quantitative The results showed a causal relationship from a good organizational climate, employee morale and commitment in an organization. Conceptual models of the organization's climate and employee morale and organizational commitment are presented that provide an explanation of the interrelationship between these variables.

Quantitative The results showed that affective commitment is strongly correlated with the five components of the organization's climate: structure, responsibility, warmth and support, conflict and expecting approval. Also, continuity commitments are impacted by three climate organizations: reward, warmth and support, and structure. In addition, normative commitments are significantly related to three climate organizations: reward, warmth and support, and expect approval.

Quantitative

The results found a positive and significant relationship among all factors. Having innovation as a core part of the company's strategy and fostering a climate for innovation 
structural equation modeling. positively affects the innovative

level and performance of a

company. This is especially true for manufacturers of secondary or value-added wood products. The climate for innovation is characterized by high levels of autonomy and drive, team cohesion, openness to change and risk-taking, and sufficient resources available to people.

Based on the findings written in Table 1 above, some aspects are observed. First, the findings shows that most of the mentioned earlier research indicated positive and significant relationship between work climate and employee performance. Only a small portion of the researches shows otherwise, that work climate doesn't have influences on organization climate (Delft, 2010; Nugroho et al., 2019; Prastiyono et al., 2020; Kusmaningtyas \& Priyana, 2013). This can be caused by various factors, This can be because the working climate consists of many dimensions and the results of the study show that from several dimensions ' work climate that has a significant influence on the performance of employees only Innovation. For Responsibilitiy, Reward, Clarity, standards have no significant effect (Delft, 2010). As for several factors, such as employees are too focused on their tasks thus ignoring their work climate (Nugroho et al., 2019) and work climate is considered as a dynamic concept that gradually changes (Prastiyono et al., 2020). Furthermore, according to Kusmaningtyas \& Priyana (2013), there are some factors causing work climate not having significant effect on employee performance, such as pressures in accomplishing targets, oftenly changing rules and policies within an organization, work partners that oftenly change, and too high working targets that needs to be achieved. Based on those, a conclussion can be taken that fundamentally, organization has a significant and positive towards employee performance. While findings that is in contrast of what mentioned before shows that there exists a barrier that prevents employee to experience work climate thus the relationship between the two can not be measured well.

On the other hand, numerous researches shows that studies regarding work climate and employee performance were mostly conducted to observe employe performance using various variables. In this context, work climate then became one of dependant variables to study employee performance. Only small portions of the study were conducted to explore the relationship between the two (Raja. S et al., 201; Mutonyi et al., 2020; Fenwick et al., 2011; Abubakr \& Bader, 2013) This then shows that organization climate is one of the factors that are considered to influence employee performance. But then, these represents that further study is required to explore specifically on the relationship of the two. This can be achieved by observing further regarding work climate components like physical environment, and psychosocial components that influence employee performance.

Reviews regarding relationship between work climate and employee performance in Indonesia mostly conducted in organizational context. Only few is taking foreign context to be studied (Abubakr \& Bader, 2013; Fenwick et al., 2011; Mutonyi et al., 2020). Therefore, in general employee performance in Indonesia is influenced by work climate within organization where they are working on. This also can be considered to be normal since Indonesian people puts social interactions as an important component of their daily lives. Thus, working environment atmosphere will impact on how they work and then influencing on their performance.

\section{Conclusion}

Based on discussion regarding the findings of earlier researches conducted, several conclusions are taken. Firstly, organization climate has a positive and significant effect on employees performance. This is based on the findings that most of the researches show a positive and significant effect between these two variable. Secondly, organization climate is just one of the factor that is considered able to influence the employee performance, so this factor can be reviewed together with other factor to verify the effect on employees performance. Lastly, Indonesian employee performances are effected by work climate within the organization where they work.

In concept, this study explains that the effects of work climate towards employee performance are positive and significant. Implying that the employee are considering that work climate is an important thing to be able improve their

Permatasari, J., \& Ratnawati, I. (2021). Work climate and employee performances: a literature observation. International Research Journal of Management, IT and Social Sciences, 8(2), 184-195.

https://doi.org/10.21744/irjmis.v8n2.1425 
performance. Fine work climate can encourage them to accomplish their task well, so that they can improve their performance. Therefore, the implications of this research for management is to maintain a good work climate in the work place is necessary. Thus manager must be able to create a fine work climate for the employees. So that the employee experiences comfortability and then encourages them to be able to work better. Especially in organizational context in Indonesia where every individuals generally put social relationship as an important thing. Nevertheless, the fact that employee performance is not only influenced by work climate can not be ignored. Therefore, manager must be able to develop various ways to improve employee performance, depends on what organization he is working at.

Furthermore, the results of earlier research indicate the review regarding relationship between work climate and employee performance are dominated by quantitative method researches. Because of that, upcoming researches in studying the relationship of the two can use qualitative method. Hopefully, by using qualitative method more deeper overview regarding organization climate that is considered to be impactful on employee performance. Deeper analysis can also be conducted to components of work climate, such as physical and psychosocial environment that influence employe performance. This will further show about how the work climate can affect employee performance. Furthermore this research has its own limitation because only a part of literature regarding relationship between work climate and employee performance used for reference. More comprehensive analysis will be needed to get more insight about the relationship between the two. Therefore, the upcoming research can use meta-analysis method on various pre-existing studies. Meta analysis will provide a statistical overview of various scientific reviews in accordance to work climate and employee performance.

\section{Conflict of interest statement}

The authors declared that they have no competing interests.

Statement of authorship

The authors have a responsibility for the conception and design of the study. The authors have approved the final article.

\section{Acknowledgments}

We are grateful to two anonymous reviewers for their valuable comments on the earlier version of this paper. 


\section{References}

Abdillah, M. R., Anita, R., \& Anugerah, R. (2017). Dampak Iklim Organisasi Terhadap Stres Kerja Dan Kinerja Karyawan. Jurnal Manajemen, 20(1), 121. https://doi.org/10.24912/jm.v20i1.69

Abdul-Nasser El-Kassar; Nour Chams; Silva Karkoulian. (2011). Organizational Climate and its Effects on the Employees Commitment. The Business Review, Cambridge , 19(1).

Abubakr, S., \& Bader, A. H. (2013). Perceived work climate and employee performance in public security organizations in the UAE. Transforming Government: People, Process and Policy, 7(3), 410-424. https://doi.org/10.1108/TG-03-2012-0001

Agarwal, P. (2015). The moderating effect of strength of organisational climate on the organisational outcomes. Journal of the Indian Academy of Applied Psychology, 41(1), 71-76.

Alberto, J., Amar, S., \& Patrisia, D. (2019, April). The Influence of Leadership, Organizational Culture and Work Climate on Employee Performance in the Department of Public Works and Spatial Planning of Padang City BT 2nd Padang International Conference on Education, Economics, Business and Accounting (PICEEBA-2 2018). 626-634. https://doi.org/https://doi.org/10.2991/piceeba2-18.2019.82

Amro, A., Hamzah, E., Lawrence, E. O., \& K., A. M. (2018). Knowledge management, workplace climate, creativity and performance: The role of authentic leadership. Journal of Workplace Learning, 30(8), 592-612. https://doi.org/10.1108/JWL-12-2017-0111

Bamel, U. K., Rangnekar, S., Stokes, P., \& Rastogi, R. (2013). Organizational climate and managerial effectiveness: An Indian perspective. International Journal of Organizational Analysis, 21(2), 198-218. https://doi.org/10.1108/IJOA-09-2011-0514

Berberoglu, A. (2018). Impact of organizational climate on organizational commitment and perceived organizational performance: Empirical evidence from public hospitals. BMC Health Services Research, 18(1), 1-9. https://doi.org/10.1186/s12913-018-3149-z

Crespell, P., \& Hansen, E. (2008). Work climate, innovativeness, and firm performance in the US forest sector: In search of a conceptual framework. Canadian Journal of Forest Research, 38(7), 1703-1715. https://doi.org/10.1139/X08-027

Delft, L. P. (2010). Organizational Climate and Performance "The relation between organizational climate and performance and an investigation of the antecedents of organizational climate." Faculty of Technology, Policy and Management, (March), 66.

Diamantidis, A. D., \& Chatzoglou, P. (2019). actors affecting employee performance: an empirical approach. International Journal of Productivity and Performance Management. 68(1), 171-193. Retrieved from https://doi.org/10.1108/IJPPM-01-2018-0012.

Duchon, D., \& Plowman, D. A. (2005). Nurturing the spirit at work: Impact on work unit performance. The leadership quarterly, 16(5), 807-833. https://doi.org/10.1016/j.leaqua.2005.07.008

Diamantidis, Anastasios D., \& Chatzoglou, P. (2019). Factors affecting employee performance: an empirical approach. International Journal of Productivity and Performance Management, 68(1), $171-193$. https://doi.org/10.1108/IJPPM-01-2018-0012

Emma, S., \& Kim, C. (2015). Proof That Positive Work Cultures Are More Productive. Harvar Business Review.

Faustino Cardoso, G. (1995). Manajemen Sumber Daya Manusia. Yogyakarta: Ando Offset.

Fay, D., \& Lührmann, H. (2004). Current themes in organizational change. European Journal of Work and Organizational Psychology, Vol. 13, pp. 113-119. https://doi.org/10.1080/13594320444000029

Fenwick, F. J., C., A. G., \& Harald, B. (2011). Organizational climate and performance in retail pharmacies. Leadership \& Organization Development Journal, 32(3), 224-242. https://doi.org/10.1108/01437731111123898

Hadian, D. (2018). the Effect of Work Climate and Work Discipline on Employee Performance (Study on One of the 3 Star Hotels in Bandung). Jurnal Computech \& Bisnis, 12(2), 162-170. https://doi.org/10.5281/zenodo.3232927

Hafee, I., Yingjun, Z., Hafeez, S., Mansoor, R., \& Rehman, K. U. (2019). Impact of Workplace Environment on Employee Performance: Mediating Role of Employee Health. Business, Management and Education, 17(2), 173193. https://doi.org/10.3846/bme.2019.10379

He, Q., An, Q., \& Li, M. (2015). How Vocational Delay of Gratification Affects Employees' Job Performance: Organizational Climate as a Moderator. Journal of Service Science and Management, 08(05), 766-772. https://doi.org/10.4236/jssm.2015.85077

Hellriegel, D., Jackson, S. E., \& Slocum, J. W. (1999). Management. Retrieved from https://books.google.com.ua/books?id=waJXAAAAYAAJ

Hellriegel, D., \& Slocum, J. W. (2004). Organizational Behavior. Retrieved from

Permatasari, J., \& Ratnawati, I. (2021). Work climate and employee performances: a literature observation. International Research Journal of Management, IT and Social Sciences, 8(2), 184-195.

https://doi.org/10.21744/irjmis.v8n2.1425 
https://books.google.com.ua/books?id=vaJXAAAAYAAJ

Hicklenton, C., Hine, D. W., \& Loi, N. M. (2019). Can work climate foster pro-environmental behavior inside and outside of the workplace? Plos One, 14(10), e0223774. Retrieved from https://doi.org/10.1371/journal.pone.0223774

Jyoti, J. (2013). Impact of Organizational Climate on Job Satisfaction, Job Commitment and Intention to Leave: An Empirical Model. Journal of Business Theory and Practice, 1(1), 66. https://doi.org/10.22158/jbtp.v1n1p66

Karakas, F. (2010). Spirituality and Performance in Organizations: A Literature Review. Journal of Business Ethics, 94(1), 89-106. https://doi.org/10.1007/s10551-009-0251-5

Khademfar, M., Iis, K., Bint Omar, Z., \& Arabamiry, S. (2013). Ethical work climate and firm performance. International Journal of Business and Social Science.

Kapp, E. A. (2012). The influence of supervisor leadership practices and perceived group safety climate on employee safety performance. Safety science, 50(4), 1119-1124. https://doi.org/10.1016/j.ssci.2011.11.011

Kawiana, I. G. P., Dewi, L. K. C., Martini, L. K. B., \& Suardana, I. B. R. (2018). The influence of organizational culture, employee satisfaction, personality, and organizational commitment towards employee performance. International research journal of management, IT and social sciences, 5(3), 35-45.

Kusmaningtyas, A., \& Priyana, P. O. (2013). The Influence of Compensation and Organization Climate on Work Motivation and Their Impact on Employee Performance of Bank XXX Corporation at Tanjung Perak. Sustainable Competitive Advantage (SCA), 2(1), 1-18.

Lamberti, G., Aluja Banet, T., \& Rialp Criado, J. (2020). Work climate drivers and employee heterogeneity. The International Journal of Human Resource Management, 1-33. https://doi.org/10.1080/09585192.2020.1711798

Li, Yee Poh \& Mahadevan, A. (2018). A Study on the Impact of Organisational Change on It Employees. International Journal of Accounting \& Business Management, 7(8), 1-5. Retrieved from http://oldror.lbp.world/UploadedData/5009.pdf

Mutonyi, B. R., Slåtten, T., \& Lien, G. (2020). Organizational climate and creative performance in the public sector. European Business Review, 32(4), 615-631. https://doi.org/10.1108/EBR-02-2019-0021

Neal, A., Griffin, M. A., \& Hart, P. M. (2000). The impact of organizational climate on safety climate and individual behavior. Safety science, 34(1-3), 99-109. https://doi.org/10.1016/S0925-7535(00)00008-4

Nugroho, N. T., Hastuti, I., \& Indah, R. P. (2019). Pengaruh Motivasi Dan Iklim Kerja Terhadap Kinerja Karyawan (Survey pada Karyawan Universitas Duta Bangsa Surakarta). Prosiding Seminar Nasional \& Call for Paper STIE $A A S$, (September), 171-176.

Permarupan, P. Y., Saufi, R. A., Kasim, R. S. R., \& Balakrishnan, B. K. P. D. (2013). The Impact of Organizational Climate on Employee's Work Passion and Organizational Commitment. Procedia - Social and Behavioral Sciences, 107, 88-95. https://doi.org/10.1016/j.sbspro.2013.12.403

Pramono, A. (2004). Analisis Keterampilan Kerja Dan Iklim Kerja Terhadap Kualitas Pelayanan Keperawatan Di Ruang Rawat Inap RSU. H. Sahudin Kutacane.

Prastiyono, U., Satriyono, G., \& Rahayu, B. (2020). Pengaruh Gaya Kepemimpinan, Budaya Organisasi Dan Iklim Kerja Terhadap Kinerja Karyawan Cv. Mitra Bhuwana Mandiri Kediri. Jurnal Riset Bisnis Dan Ekonomi, 1. Retrieved from http://dx.doi.org/10.30737/risk.v1i2.1388

Pant, I., \& Yadav, R. K. (2016). Impact of emotional intelligence on the job performance of employee. International Research Journal of Management, IT and Social Sciences, 3(1), 7-14.

Permarupan, P. Y., Saufi, R. A., Kasim, R. S. R., \& Balakrishnan, B. K. (2013). The impact of organizational climate on employee's work passion and organizational commitment. Procedia-Social and Behavioral Sciences, 107, 8895. https://doi.org/10.1016/j.sbspro.2013.12.403

Putra, K. (2018). Pengaruh Profesionalisme dan Iklim Kerja terhadap Kinerja Karyawan pada PT. Bank Tabungan Negara Kantor Cabang Malang. JAMIN: Jurnal Aplikasi Manajemen Dan Inovasi Bisnis, 1(1), 61. https://doi.org/10.47201/jamin.v1i1.6

Raja. S, Madhavi, C., \& Sankar, S. (2019). Influence of Organizational Climate on Employee Performance in Manufacturing Industry. Suraj Punj Journal For Multidisciplinary Research, 9(3), 146-157. https://doi.org/16.10089.SPJMR.2018.V9I3.16.3243

Rivai, V. (2013). Kepemimpinan dan perilaku organisasi (Ketiga).

Robbins, S. P., \& Coulter, M. (2016). Manajemen. Journal of Chemical Information and Modeling, 53(9), 1689-1699.

Shilpa, W. (2015). The international journal of business \& management Impact of Effective Employee Performance Management on Organizational. 3(11), 183-196. 
Siregar, F. L. S., \& Evanita, S. (2020). The Effect of Transformational Leadership, Organization Climate and Work Discipline on Employee Performance at Royal Denai Group Hotel Bukittinggi BT - 4th Padang International Conference on Education, Economics, Business and Accounting (PICEEBA-2 2019). 749-754. https://doi.org/https://doi.org/10.2991/aebmr.k.200305.141

Sleight \& Tiffin., \& Vickroy, Shaw, \& F. (1997). Industrial noise and hearing conservation. Current Opinion in Otolaryngology and Head and Neck Surgery, 5(5), 330-333. https://doi.org/10.1097/00020840-199710000-00013

Snell, S. A., \& Bateman, T. S. (2018). Management: Leading \& Collaborating in a Competitive World (13th, berilu ed.). Retrieved from https://books.google.com.ua/books?id=aCVoswEACAAJ

Shanker, R., Bhanugopan, R., Van der Heijden, B. I., \& Farrell, M. (2017). Organizational climate for innovation and organizational performance: The mediating effect of innovative work behavior. Journal of vocational behavior, 100, 67-77. https://doi.org/10.1016/j.jvb.2017.02.004

Subramani, A. K., Akbar Jan, N., Moideen Batcha, H., \& Vinodh, N. (2016). Use of structural equation modeling to empirically study the impact of organizational climate on employees' work related attitude in information technology organizations in Chennai City. Indian Journal of Science and Technology, 9(2). https://doi.org/10.17485/ijst/2016/v9i2/86353

Thanh, D. T. (2018). How spirituality, climate and compensation affect job performance. Social Responsibility Journal, 14(2), 396-409. https://doi.org/10.1108/SRJ-05-2016-0086

Permatasari, J., \& Ratnawati, I. (2021). Work climate and employee performances: a literature observation. International Research Journal of Management, IT and Social Sciences, 8(2), 184-195. 